\title{
Communication
}

[Comunicação]

\section{Quantitative computed tomography of the renal cortex in healthy dogs and cats}

\author{
[Tomografia computadorizada quantitativa do córtex renal de cães \\ e gatos hígidos] \\ D.C. Oliveira ${ }^{1}$, L.A.V.S. Costa ${ }^{2}$, I.C.C. Silva ${ }^{2}$, M.W. Teixeira ${ }^{2}$, F.S. Costa ${ }^{2 *}$ \\ ${ }^{1}$ Universidade Federal do Espírito Santo - Alegre, ES \\ ${ }^{2}$ Universidade Federal Rural de Pernambuco - Recife, PE
}

Computed tomography exam presents a wide variety of indications for dogs and cats, and is an important tool to the establishment of innumerable diagnoses (Teixeira et al., 2007). Tomographic radiodensity estimation in the abdominal organs can be performed with high precision and reproducibility, aiding in the diagnosis of several diseases (Seeram, 2008). For a more efficient computed tomography exam, a detailed knowledge of the normal presentation of each organ is indispensable, as well as the knowledge of species-specific variations and alterations. Renal cortex radiodensity evaluation is widely used in humans (Michaely et al., 2008), but just a few studies approach its clinical application in dogs and cats (Reichle et al., 2002; Tidwel et al., 2007). Differences in the deposition of lipidic content in the kidneys of dogs and cats have already been characterized (Modell, 2005). However, normal renal radiodensity values specific for each species have not been stipulated yet. This study characterizes and compares the renal cortex radiodensity in healthy dogs and cats by means of helical computed tomography exam.

This study has the approval of the Ethics and Animal Experimentation Committee at the Universidade Federal do Espírito Santo, UFES, Brazil. Both dogs and cats used in this experiment were selected from Espírito Santo State Animal Shelters, and during the realization of the exams they were kept in wide collective shelters with access to solar light, receiving water and premium dry food. After the end of the examinations, all animals were donated for adoption.

For the selection of the experimental group, triage exams were performed, which involved a detailed clinical and ultrasonographic evaluation of the abdominal cavity, as well as full blood counts, urine analyses and serum-level dosage of ALT (alanine aminotransferase), AST (aspartate aminotransferase), ALP (alkaline phosphatase), GGT (gamma-glutamyltransferase), blood urea nitrogen (BUN), creatinine, total protein, albumin, cortisol, free T4 and total T4. Ten nonneutered/non-spayed mixed-breed young dogs (five males and five females) with age ranging from 12 to 36 months, and with body weight ranging from 10 to $15 \mathrm{~kg}$, were used. There were also selected ten non-neutered/non-spayed mixed-breed young cats (four males and six females) with age ranging from 12 to 36 months, and with body weight ranging from 3 to $4 \mathrm{~kg}$.

Prior to the helical computed tomography exam, the animals were submitted to alimentary fasting for 12 hours. The cephalic vein in the dogs was catheterized and fluid therapy was instituted with a physiologic solution, anesthesia was then induced with diazepam and propofol. In the cats, an intramuscular dissociative anesthesia was administered with midazolam and ketamina. During the exam, the animals were kept in a right lateral decubitus position.

Recebido em 25 de maio de 2012

Aceito em 17 de abril de 2013

*Autor para correspondência (corresponding autor)

E-mail: fabianosellos@hotmail.com 
Using a helical computed tomography scanner (Hi-Speed FX/i CT Scanner, General Electric Medical Systems, Waukesha, WI), 2mm contiguous transverse images were acquired from the diaphragm dome to the iliac crests. Technical factors were $120 \mathrm{kVp}$ and auto-mA at a speed of one rotation per second. To enhance the evaluation of the liver and kidneys, a narrow window was chosen (window width $=400$, window level $=40$ ). The computed tomography machine was properly calibrated before each exam for a better standardization of the results. The original tomographic data were transferred as DICOM images to an image analysis software
(eFilm version 2.1.2, Merge Healthcare, Milwaukee, WI) to perform the image analysis.

In order to determine the radiodensity of the renal cortex, three regions of interest were selected in each kidney in three different slices, which consisted of the cranial pole (Fig. 1A and 2A), renal hilum (Fig. 1B and 2B) and caudal pole (Fig. 1C and 2C). The radiodensity of the renal cortex was estimated using the mean value of the values obtained in each region of interest in both left and right kidneys. Each region of interest had an average area of $10 \pm 0.1 \mathrm{~mm}^{2}$.
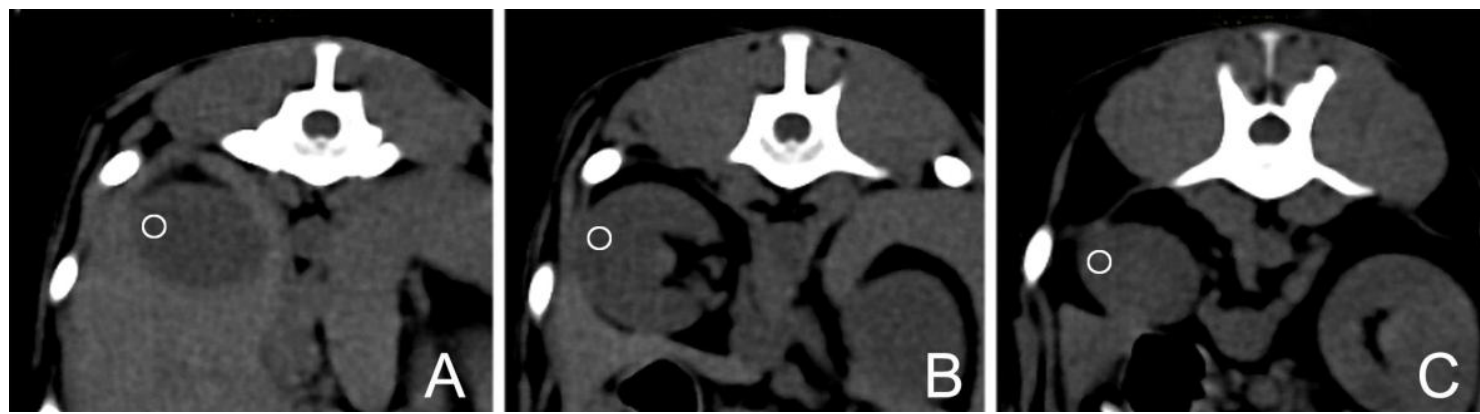

Figure 1. Transverse computed tomography images of the abdomen of a healthy adult mixed-breed dog demonstrating the selection of three regions of interest (white circles) in the renal cortex of the right kidney: (A) cranial pole, (B) renal hilum and (C) caudal pole.
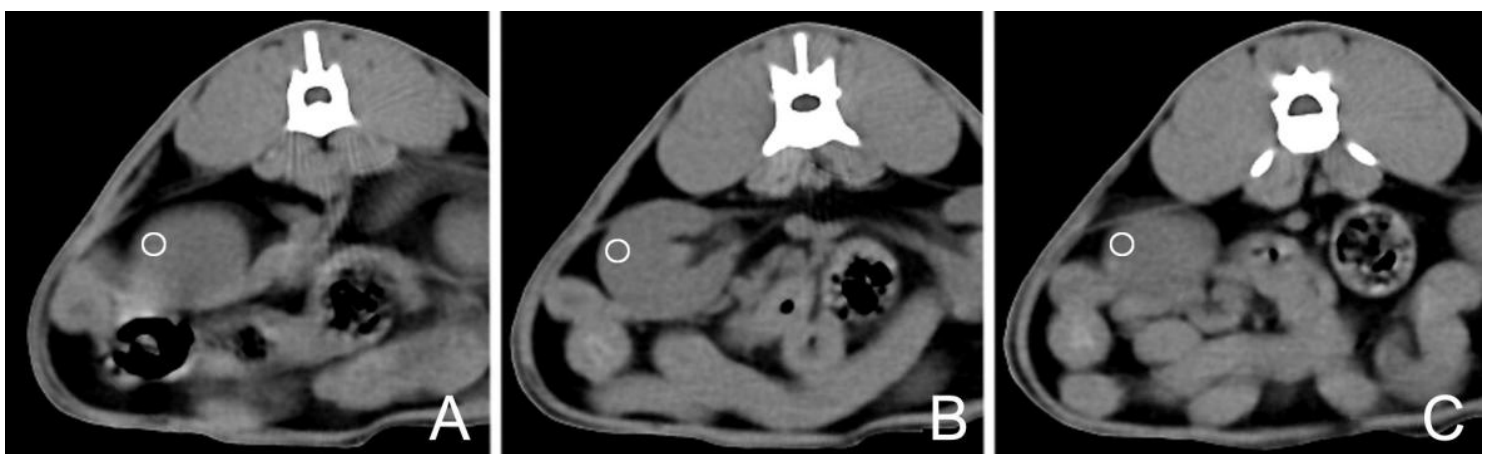

Figure 2. Transverse computed tomography images of the abdomen of a healthy adult mixed-breed cat demonstrating the selection of three regions of interest (white circles) in the renal cortex of the right kidney: (A) cranial pole, (B) renal hilum and (C) caudal pole.

For the statistical analysis of the variables, the Shapiro-Wilk's multivariate normality test was applied first, verifying that the variables presented a normal distribution. The comparative analysis of the renal cortical radiodensity in dogs and cats was performed with paired t-test for independent samples, using a significance level of $1 \%(P<0.01)$.
As demonstrated in Table 1, it was verified a greater degree of $\mathrm{x}$-ray attenuation in the renal cortex of dogs when compared to cats. The mean radiodensities of the renal cortex of the dogs and the cats evaluated in this study were 28.4 \pm 4.7 and 22.4 \pm 3.6 Hounsfield units (HU), respectively, characterizing a difference in radiodensity of approximately 6 HUs. 
Quantitative computed...

Table 1. Mean values of renal cortex radiodensity in clinically normal dogs and cats evaluated by quantitative computed tomography

\begin{tabular}{ccccc}
\hline \multirow{2}{*}{ ROI } & \multicolumn{2}{c}{ Dogs $(\mathrm{n}=10)$} & \multicolumn{2}{c}{ Cats $(\mathrm{n}=10)$} \\
\cline { 2 - 5 } & $x \pm \mathrm{sd}$ & $95 \% \mathrm{CI}$ & $x \pm \mathrm{sd}$ & $95 \% \mathrm{CI}$ \\
\hline Cranial pole & $29.1 \pm 5.8 \mathrm{HUa}$ & $(26.5-31.6)$ & $22.1 \pm 4.8 \mathrm{HUb}$ & $(20.1-24.2)$ \\
Renal hilum & $28.8 \pm 4.9 \mathrm{HUa}$ & $(26.7-30.1)$ & $22.6 \pm 4.5 \mathrm{HUb}$ & $(20.6-24.6)$ \\
Caudal pole & $27.8 \pm 6.5 \mathrm{HUa}$ & $(25.0-30.1)$ & $22.5 \pm 4.0 \mathrm{HUb}$ & $(20.7-24.3)$ \\
Mean & $28.4 \pm 4.7 \mathrm{HUa}$ & $(26.3-30.5)$ & $22.4 \pm 3.6 \mathrm{HUb}$ & $(20.8-24.0)$ \\
\hline
\end{tabular}

ROI, region of interest; $x \pm$ sd, mean \pm standard deviation; 95\% CI, 95\% confidence interval; HU, Hounsfield unities. The paired t-test for independent samples was applied since the results followed normal distribution. Means followed by distinct letters in the same line differ statistically $(P<0.01)$.

In veterinary medicine, computed tomography is a current imaging method, which is in expansion. This technique provides valuable and complementary information to those obtained through conventional imaging diagnostic methods, such as radiographic and ultrasonographic exams (Smallwood and George, 1993; Ohlerth and Sharf, 2007).

Previous studies demonstrated that computed tomography in humans can be used to characterize an increase in renal density, as a result of glycogen accumulation, making it necessary to establish a differential diagnosis of diffused nephrocalcinosis resulting from congenital hypercalcemia and oxalosis (Doppman et al., 1982). The diagnosis of several other kidney diseases in human patients, such as necrosis, ischemia, cystic lesions and neoplastic processes can be aided by quantitative computed tomography (Doppman et al., 1982; Michaely et al., 2008).

Some studies have already used computed tomography for the diagnosis of urinary tract diseases in dogs and cats, such as the identification of renal neoplasms in dogs and cats (Yamazoe et al., 1994), early detection of cystadenocarcinomas in dogs (Moe and Lium, 1997) and polycystic kidney disease in cats (Reichle et al., 2002). Little information is described regarding the degree of X-ray attenuation of the renal cortex in dogs and cats, and no differentiation between these species is mentioned either. After performing a broad bibliographical review, some authors mentioned normal values of renal radiodensity for small animals ranging from 20 to $40 \mathrm{HU}$ (Ohlerth and Sharf, 2007), while other study mentioned normal values of radiodensity of the organ as 30 HU (Tidwel et al., 2007).
As mentioned in the literature, the characterization of the differences between the species is important for a better interpretation of the tomographic findings (Smallwood and George, 1993). The results of the present study demonstrate that the renal cortex of healthy dogs is hyperattenuated when compared with the renal cortex of healthy cats. There are histological differences between the renal cortex of dogs and cats, since there is a greater deposition of lipids in cats kidneys. Studies indicated that the lipidic deposits in cats kidneys are located in the renal cortex region, especially in the epithelium of the proximal contorted tubules (Modell, 2005). The $\mathrm{X}$-ray absorption degree in the patient is directly proportional to the linear attenuation coefficient and thickness of the tissue through which the radiation passes. The linear attenuation coefficient is dependent on the density of the tissue. High density tissues have greater absorption rates when compared with tissues of low density (Ohlerth and Sharf, 2007; Tidwel et al., 2007). Thus, the greater lipidic deposition verified in the kidneys of cats seems to be the factor responsible for the reduction of its density, making them hypoattenuated when compared to the kidneys of dogs.

In the present research, the authors were careful to standardize the sizes of the regions of interest, so that each region of interest presented an area of $10 \pm 0.1 \mathrm{~mm}^{2}$. Studies performed in humans with the intent of characterizing hepatic radiodensity and estimating the amount of fat in the organ have verified that the size standardization of the regions of interest is important and provides greater precision in the results (Kodama et al., 2007). It must be emphasized that, in order to determine the radiodensity of the renal cortex, this study did not use intravenous contrast. According to the literature, despite favoring the identification of 
vascular structures, the radiographic contrast interferes directly in the radiodensity of the tissue, providing a false result (Seeram, 2008).

In the present study, it can be concluded that due to a greater deposition of lipidic content, the cortical region of cats kidneys is hypoattenuated when compared to the renal cortex of dogs. This difference must be taken into consideration when interpreting the computed tomographic exams in these species for a better interpretation of the findings.

Keywords: dog, cat, renal cortex, computed tomography, radiodensity

\section{RESUMO}

Este estudo caracteriza a radiodensidade do córtex renal de 10 cães e 10 gatos adultos, clinicamente saudáveis, por meio de exames de tomografia computadorizada helicoidal. Em cada rim, a radiodensidade renal foi estimada pelo valor médio das três regiões de interesse na região cortical, selecionados no polo cranial, polo caudal e hilo renal. A radiodensidade média do córtex renal nos cães

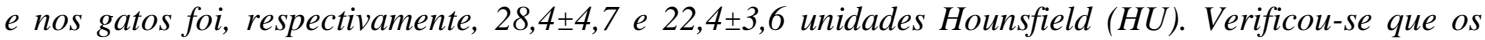
gatos possuem córtex renal hipoatenuante quando comparado com cães, um fato que está associado à maior deposição de conteúdo lipídico nos rins felinos. A diferença na radiodensidade encontrada entre o córtex renal de cães e de gatos é importante para uma correta interpretação dos achados renais no exame tomográfico.

Palavras-chave: cão, gato, córtex renal, tomografia computadorizada, radiodensidade

\section{REFERENCES}

DOPPMAN, J.L.; CORNBLATH, M.; DWYER, A.J. et al. Computed tomography of the liver and kidneys in glycogen storage disease. J. Comput. Assist. Tomo., v.6, p.67-71, 1982.

KODAMA, Y.; NG, C.S.; WU, T.T. et al. Comparison of CT methods for determining the fat content of the liver. Am. J. Roentg., v.188, p.1307-1321, 2007.

MICHAELY, H.J.; REICHERT, M.; WECKBACH, S.; SCHOENBERG, S.O. Vascular and parenchymal diseases of the kidney. Der. Radiologe, v.48, p.185-200, 2008.

MODELL, W. Observations on the lipoids in the renal tubule of the cat. Anat. Rec., v.57, p.13-27, 2005.

MOE, L.; LIUM, B. Computed tomography of hereditary multifocal renal cystadenocarcinomas in German shepherd dogs. Vet. Radio. Ultrasound., v.38, p.335-343, 1997.

OHLERTH, S.; SHARF, G. Computed tomography in small animals: basic principles and state of the art applications. The Vet. J., v.173, p.254-271, 2007.
REICHLE, J.K.; DIBARTOLA, S.P.; LÉVEILLÉ, R. Renal ultrasonographic and computed tomographic appearance, volume, and function of cats with autosomal dominant polycystic kidney disease. Vet. Radiol. Ultrasound., v.43, p.368-373, 2002.

SEERAM, E. Computed Tomography: Physical Principles, Clinical Applications, and Quality Control. 3.ed. Philadelphia: Saunders Elsevier, 2008. 536p.

SMALLWOOD, J.E.; GEORGE, T.F. Anatomic atlas for computed tomography in the mesaticephalic dog: thorax and cranial abdomen. Vet. Radiol. Ultrasound., v.34, p.65-83, 1993.

TEIXEIRA, M.; GIL, F.; VÁZQUEZ, J.M. et al. Helical computed tomographic anatomy of the canine abdomen. Vet. J., v.174, p.133-138, 2007.

TIDWEL, A.S. Principles of computed tomography and magnetic resonance imaging. In: THRALL, D.E. 5.ed. Textbook of Veterinary Diagnostic Radiology. St. Louis: Saunders Elsevier, 2007. p.50-77.

YAMAZOE, K.; OHASHI, F.; KADOSAWA, T. et al. Computed tomography on renal masses in dogs and cats. J. Vet. Med. Sci., v.56, p.813-816, 1994. 